\title{
PEMANFAATAN HASIL MODIFIKASI PEMBELAJARAN PENDIDIKAN JASMANI DI SLB-YPAC CABANG MEDAN
}

\author{
M. Wanda Aginta Bangun \\ Correspondence: Program Studi Pendidikan Olahraga Pascasarjana UNJ, \\ Jakarta, Indonesia \\ E-mail: oneginta@gmail.com
}

\begin{abstract}
Abstrak
Tujuan penelitian ini adalah untuk mengetahui bagaimana pemanfaatan hasil modifikasi pembelajaran pendidikan jasmani SLB-YPAC Cabang Medan. Metode penelitian dilakukan dengan menggunakan tehnik survey yang menggunakan observasi, wawancara, dan dokumentasi. Jumlah sampel dalam pelaksanaan penelitian ini sebanyak 1 orang, yakni guru pendidikan jasmani. Instrumen penelitian yang digunakan oleh peneliti adalah dengan mengobservasi, wawancara, yang menggunakan angket ditujukan hanya untuk guru pendidikan jasmani, serta dengan menggunakan dokumentasi. Hasil analisis data yang menggunakan tehnik presentase menunjukkan bahwa proses pemanfaatan hasil modifikasi pembelajaran pendidikan jasmani di SLB-YPAC Cabang Medan sudah baik. Dimana guru pendidikan jasmani telah memodifikasi dan dapat memanfaatkan hasil modifikasi pembelajaran pendidikan jasmani tersebut dengan baik. Pemanfaatan hasil modifikasi pembelajaran pendidikan jasmani di SLB-YPAC Cabang Medan adalah dalam katagori tinggi.
\end{abstract}

\section{Kata Kunci: Hasil Modifikasi Pembelajaran, Pendidikan Jasmani}

\section{Pendahuluan}

Manusia diciptakan di dunia mempunyai Hak Asasi Manusia (HAM) yang sama. Demikian juga dalam hal memperoleh pendidikan, dan setiap warga Negara berhak memperoleh pendidikan yang sama, baik anak yang normal maupun yang tidak normal anak berkebutuhan khusus (ABK). Tidak semua anak dilahirkan Sempurna, ternyata ada sebagian kecil yang mengalami kelainan sehingga mengalami hambatan-hambatan baik dalam perkembangan fisik maupun dalam perkembangan mentalnya. Anak yang seperti ini diklasifikasikan sebagai anak luar biasa.

Seperti anak yang lain, anak-anak luar biasa juga merupakan bagian dari generasi yang harus memperoleh kesempatan untuk mengembangkan dirinya. Perlu diingat bahwa anak berkebutuhan khusus juga merupakan anak bangsa yang dapat tumbuh dan berkembang menjadi dewasa yang mempuyai rasa percaya diri dan harga diri yang tinggi dalam memimpin dan mengabdikan dirinya pada masa yang akan datang. Pada umumnya masyarakat memandang kecacatan fisik dan mental sebagai penghalang untuk melakukan sesuatu. Fenomena ini terbukti dengan sedikitnya persentase anak penyandang cacat yang mendapatkan layanan pendidikan.

Pendidikan bagi anak cacat mental sangat penting karena mereka mempunyai tingkat inteligensi di bawah rata-rata anak normal, dengan demikian pendidikan bagi anak cacat memerlukan kurikulum khusus, tenaga pendidik 
khusus dan media khusus yang telah disesuaikan dengan tingkat kecacatannya masing-masing. Pendidikan Jasmani Adaptif pada anak cacat melibatkan guru pendidikan jasmani yang telah mendapatkan pelatihan khusus pendidikan jasmani adaptif dan dapat menyusun program pengajaran sehingga dapat di sesuaikan dengan keadaan anak cacat dengan keterbatasan yang dimilikinya. Jadi anak cacat harus lebih mendapatkan perlakuan yang lebih khusus. Selain itu guru juga harus bisa memanfaatkan peralatan pembelajaran yang dimodifikasi dan guru juga harus melihat perkembangan anak cacat tersebut.

Tujuan penelitian ini adalah untuk mengetahui perlatan yang dimodifikasi dan seberapa besar pemanfaatan hasil modifikasi peralatan pembelajaran penjas di SLB-YPAC Cab. Medan. Penelitian ini diharapkan dapat memberikan manfaat langsung kepada antara lain sebagai berikut: (a) Guru pendidikan jasmani yang mengajar di sekolah-sekolah agar dapat mengenali masalah dan tolak ukur. (b) Para pembaca hasil penelitian ini, agar dapat memahami dan dapat dipahami sebagai mana mestinya. (c) Peneliti melakukannya agar dapat dijadikan bahan masukkan, atau referensi pengembangan.

Pada hakikatnya pendidikan jasmani adalah suatu proses interaksi yang bersifat manusiawi, upaya untuk menyiapkan peserta didik, upaya untuk peningkatkan kualitas hidup, kegiatan yang dilakukan seumur hidup. Penerapan interaksi yang dimaksud adalah adanya hubungan timbal-balik (komunikasi dua arah).

Menurut Rijsdorp (dalam irfan 2007), mengemukakan bahwa: "pendidikan jasmani adalah segala yang berpangkal pada gerak manusia, serta mengarah kepada kepribadian yang bulat dan kreatif dari manusia, merupakan dasar dari segala pendidikan".

Selanjutnya E Mulyasa (2003) mengutarakan pendidikan jasmani adalah: "proses pendidikan yang melalui memanfaatkan aktifitas jasmani yang melalui penyediaan pengalaman belajar kepada peserta didiknya berupa aktifitas jasmani, bermain dan atau olahraga yang direncanakan secara sistematik dengan memperhatikan tahap pertumbuhan dan perkembangan guna merangsang perkembangan fisik, keterampilan berpikir, emosional, sosial dan moril”.

Apabila kita membicarakan Pendidikan Luar Biasa yang dalam bahasa Inggris disebut "Special Education", maka tidak bisa lepas dengan Anak Berkebutuhan Khusus atau Exceptional Children. Untuk Anak Berkebutuhan Khusus dikenal juga istilah anak cacat, anak berkelainan, anak tuna dan dalam pembelajarannya menjadi salah satu kelompok anak yang memiliki kebutuhan khusus. Dalam penggunaan istilah tersebut anak berkebutuhan khusus di atas memiliki konsekuensi berbeda. Istilah yang paling tepat tergantung dari mana kita memandang. Seperti dalam bahasa Inggris dikenal istilah Impairment, disability, handicap. Impairment berhubungan dengan penyakit dan kelainan pada jaringan. Disability berhubungan dengan kekurangan/kesalahan fungsi atau tidak adanya bagian tubuh tertentu. Handicap berhubungan dengan kelainan dan ketidakmampuan yang dimiliki seseorang bila berinteraksi dengan lingkungan.

Pada akhir perkembangan sekarang ini, anak luar Biasa sudah mulai dianggap sebagai manusia biasa sama seperti yang lain. Anak berkebutuhan 
khusus memiliki hak yang sama, hal ini menimbulkan perlakuan yang wajar seperti pada anak yang lain yaitu dididik dan disekolahkan. Perbedaannya hanya terletak pada adanya kelaian yang disandangnya, Kelainan bisa terletak pada fisiknya, mentalnya, sosialnya atau perpaduan ketiganya. Mereka mengalami kelainan sedemikian rupa sehingga membutuhkan pelayanan pendidikan luar biasa. Dengan sikap ini maka anak berkebutuan khusus memiliki hak yang sama dengan anak biasa lainnya. Dengan sikap ini timbul deklarasi hak asasi manusia penyandang cacat yang meliputi:

1. Hak untuk mendidik dirinya. (The Right to Educated Oneself)

2. Hak untuk pekerjaan dan profesi. (The Right to Occupation or Profession)

3. Hak untuk memelihara kesehatan dan fisik secara baik (The Right to Maintain Health and Physical Well Being)

4. Hak untuk hidup mandiri (the Right to Independent Living)

5. Hak untuk kasih sayang (Right to Love)

Pengelompokan anak berkebutuhan khusus Untuk keperluan Pendidikan Luar Biasa, Anak Berkebutuhan Khusus dapat dibagi kedalam 2 (dua) kelompok yaitu:

1. Masalah (problem) dalam Sensorik motorik. Anak yang mengalami kelainan dan memiliki efek terhadap kemampuan melihat, mendengar dan kemampuan bergeraknya. Problem ini kita sebut Sensorik motorik Problem. Kelainan sensorik motorik biasanya secara umum lebih mudah diidentifikasi, ini tidak berarti selalu lebih mudah dalam menemukan kebutuhannya dalam pendidikan. Kelainan sensorik motorik tidak harus berakibat masalah pada kemampuan inteleknya. Sebagian besar anak yang mengalami masalah dalam sensorik motorik dapat belajar dan bersekolah dengan baik seperti anak yang tidak mengalami kelainan.

Ada tiga (3) jenis kelainan yang termasuk problem dalam sensorik motorik yaitu:
a. Hearing disorders (Kelainan pendengaran atau tuna rungu)
b. Visual Impairment.(kelainan penglihatan atau tuna netra)
c. Physical Disability (kelainan fisik atau tuna daksa)

Setiap jenis kelainan tersebut akan melibatkan berbagai keahlian di samping guru khusus yang memiliki keterampilan dan keahlian khusus sesuai kebutuhan setiap jenis kelainan. Kerjasama sebagai tim dari setiap ahli sangat penting untuk keberhasilan pembelajaran anak berkebutuhan khusus.

2. Masalah (problem) dalam belajar dan tingkah laku. Kelompok anak berkebutuhan khusus yang mengalami problem dalam belajar adalah:

a. Intellectual Disability (keterbelakangan mental atau tuna grahita)

b. Learning disability (ketidakmampuan belajar atau kesulitan belajar khusus)

c. Behavior disorders (anak nakal atau tuna laras)

PJKR_

http://jurnal.unimed.ac.id/2012/index.php/jpehr/index 
d. Giftet dan talented (anak berbakat)

e. Multy handicap (cacat lebih dari satu atau tuna ganda)

3. Penyebab kelainan pada anak berkebutuhan khusus. Secara umum dapat dijelaskan bahwa penyebab terjadinya kelainan pada anak berkebutuhan khusus bisa dibagi atau dikelompokkan menjadi tiga (3) yaitu:

a) Pre Natal (sebelum kelahiran), sebelum kelahiran dapat terjadi di saat konsepsi atau bertemunya sel sperma dari bapak bertemu dengan sel telur ibu, atau juga dapat terjadi pada saat perkembangan janin dalam kandungan. Kejadian tersebut disebabkan oleh faktor internal yaitu faktor genetik dan keturunan. Penyebab kelainan prenatal dari faktor eksternal dapat berupa Ibu yang terbentur kandungannya, karena jatuh sewaktu hamil, atau memakan makanan atau obat yang menciderai janin dan sebagainya.

b) Natal (di saat melahirkan), pada saat ibu sedang melahirkan bisa menjadi penyebab, misalnya kelahiran yang sulit, pertolongan yang salah, infeksi karena ibu mengidap Sepilis dan sebagainya.

c) Post Natal. Kelainan terjadi pada Post Natal artinya kelainan yang disebabkan oleh faktor setelah anak ada di luar kandungan. Ini dapat terjadi karena kecelakaan, keracunan dan sebagainya.

Pendidikan jasmani merupakan bagian integral dari sistem pendidikan secara keseluruhan. Pendidikan sebagai proses pembinaan manusia yang berlangsung seumur hidup, mempunyai peranan yang sangat penting yaitu memberi kesempatan kepada siswa untuk terlibat langsung dalam aneka pengalaman belajar melalui aktivitas jasmani. Pendidikan jasmani merupakan proses pendidikan yang memanfaatkan aktivitas jasmani yang direncanakan secara sistematik, bertujuan untuk meningkatkan individu secara organik, neuromuscular, perceptual, kognitif, sosial dan emosional.

Esensi modifikasi adalah menganalisa sekaligus mengembangkan materi pelajaran dengan cara meruntunkannya dalam bentuk aktivitas belajar yang potensial dapat memperlancar siswa dalam belajarnya. Cara ini dimaksudkan untuk menuntun, mengarahkan, dan membelajarkan siswa dari yang tadinya tidak bisa menjadi bisa, dari tingkat yang tadinya lebih rendah menjadi memiliki tingkat yang lebih tinggi. Bahagia dan Suherman (2000)

Pengertian Modifikasi secara umum (on line) adalah mengubah atau menyesuaikan. Mengenai pengertian modifikasi, Bahagia (2010), mengemukakan bahwa: Modifikasi dapat diartikan sebagai upaya melakukan perubahan dengan penyesuaian-penyesuaianbaik dalamsegi fisik material (fasilitas dan perlengkapan) maupun dalam tujuan dan cara (metoda, gaya, pendekatan, aturan serta penilaian) dari pernyataan diatas mengenai pengertian modifikasi, modifikasi merupakan suatu usaha perubahan yang dilakukan berupa penyesuaianpenyesuaian baik dalam bentuk fasilitas dan perlengkapan atau dalam metoda, gaya, pendekatan, aturan serta penilaian.

Tujuan modifikasi menurut Lutan (1988) yang dikutip Bahagia (2010), bahwa: Modifikasi dalam mata pelajaran pendidikan jasmani diperlukan dengan tujuan agar: a) Siswa memperoleh kepuasan dalam mengikuti pelajaran. b) 
Meningkatkan kemungkinan keberhasilan dalam berpartisipasi. c) Siswa dapat melakukan pola gerak secara benar. Sedangkan tujuan modifikasi menurut Bahagia dan Suherman (2000), sebagai berikut:

4. Modifikasi tujuan pembelajaran

5. Modifikasi materi pembelajaran

6. Modifikasi lingkungan pembelajaran

7. Modifikasi evaluasi pembelajaran.

\section{Metode}

Populasi dalam penelitian ini adalah media pembelajaran penjas yang dimodifikasi, guru penjas, kepala sekolah dan semua siswa SLB-YPAC Cabang Medan Tahun Ajaran 2013/2014. Sempel adalah sebagian atau wakil dari populasi yang di teliti. Sampel yang digunakan dalam penelitian ini adalah peralatan pembelajaran yang dimodifikasi, guru penjas dan kepala sekolah sebanyak 2 orang.

Metode penelitian yang digunakan dalam penelitian ini adalah metode deskriptif dengan tehnik survey dengan cara mengobservasi/mengamati. Menurut Sofian Effendi Tukiran (2012), survey adalah penelitian yang mengambil sampel dari satu populasi dan menggunakan kuesioner sebagai alat pengumpulan data yang pokok.

Instrumen (alat pengumpul data) yang digunakan dalam penelitian ini adalah dengan cara mengobservasi, wawancara, dan dokumentasi. Dalam penelitian ini instrumen yang digunakan disesuaikan dengan permasalahan dan data yang dikumpulkan. Dalam instrument penelitian ini dilakaukan dengan cara mengobservasi, wawancara, dan dokumentasi, yang menggunakan angket. Angket tersebut berbentuk tertutup, alternatif jawaban dimana setiap jawaban memiliki skor sebagai berikut:
a. $\mathrm{YA}=1$
b. Tidak $=0$

Adapun kisi-kisi penelitiannya yaitu sebagai berikut:

Tabel 1. Kisi-Kisi Format Angket Instrumen Penelitian

\begin{tabular}{|c|c|c|c|c|}
\hline No & $\begin{array}{l}\text { Variabel } \\
\text { Penelitian }\end{array}$ & Indikator & Sub Indikator & $\begin{array}{c}\text { No } \\
\text { Item } \\
\text { Tes }\end{array}$ \\
\hline 1 & $\begin{array}{l}\text { Pemanfaatan hasil } \\
\text { modifikasi } \\
\text { pembelajaran } \\
\text { pendidikan } \\
\text { jasmani di SLB- } \\
\text { YPAC. Cabang }\end{array}$ & $\begin{array}{l}\text { Pembelajaran } \\
\text { pendidikan jasmani }\end{array}$ & $\begin{array}{ll}> & \text { Persiapan guru sebelum } \\
& \text { pembelajaran } \\
> & \text { Kegiatan pendahuluan } \\
> & \text { Kegiatan inti } \\
> & \text { Kegiatan penutup }\end{array}$ & $\begin{array}{l}1-5 \\
6-10 \\
11-20 \\
21-25\end{array}$ \\
\hline
\end{tabular}




$\begin{array}{llr}\text { medan } & >\text { Konsep modifikasi } & 26-30 \\ \text { modifikasi } & >\text { Tujuan modifikasi } & 31-35 \\ & >\text { Struktur modifikasi } & 36-40 \\ & & \text { pembelajaran } \\ & >\begin{array}{l}\text { Langkah-langkah / prosedur } \\ \text { modifikasi }\end{array} & 41-45\end{array}$

Tehnik analisis data yang dilakukan untuk dapat mengetahui data yang diperoleh, maka dihitung persentase dengan rumus menurut Sujana (1989).

$$
P=\frac{F}{N} X 100 \%
$$

\section{Pembahasan}

Berdasarkan penelitian dilapangan/lokasi SLB-YPAC Cabang Medan. Dengan cara terlebih dahulu melaksanakan observasi tahap 1 dan melakukan penyebaran angket pada tahap yang ke 2 pada guru pendidikan jasmani SLBYPAC Cabang Medan sebanyak 2 orang. Maka di peroleh hasil peneltian di masing-masing guru sebagai berikut:

a. Guru pendidikan jasmani, berdasarkan penelitian yang telah di laksanakan pembelajaran pada persiapan guru sebelum pembelajaran rata-rata menjawab "ya" dengan jumlah 5 soal mendapat skor 5. Selanjutnya kegiatan pendahuluan dengan 5 butir soal guru mendapat skor 4, dalam kegiatan inti dengan 10 soal guru mendapat skor 10, dalam kegiatan penutup sebanyak 5 soal guru mendapat skor 4. Pemanfaatan hasil modifikasi pada konsep modifikasi dengan jumlah soal 5 guru mendapat skor 5, dalam tujuan modifikasi dengan jumlah soal 5 guru mendapat 5 skor, struktur modifikasi pembelajaran dengan jumlah soal 5 guru mendapat 4, selanjutnya langkah-langkah/ prosedur modifikasi dengan jumlah soal 5 sehingga mendapat skor 4.

b. Kepala sekolah, berdasarkan penelitian yang telah di laksanakan pembelajaran pada persiapan guru sebelum pembelajaran rata-rata menjawab "ya" dengan jumlah 5 soal mendapat skor 4. Selanjutnya kegiatan pendahuluan dengan 5 butir soal guru mendapat skor 2, dalam kegiatan inti dengan 10 soal guru mendapat skor 7, dalam kegiatan penutup sebanyak 5 soal guru mendapat skor 3. Pemanfaatan hasil modifikasi pada konsep modifikasi dengan jumlah soal 5 guru mendapat skor 5, dalam tujuan modifikasi dengan jumlah soal 5 guru mendapat 4 skor, struktur modifikasi pembelajaran dengan jumlah soal 5 guru mendapat 4, selanjutnya langkah-langkah/ prosedur modifikasi dengan jumlah soal 5 sehingga mendapat skor 2 .

Berdasarkan hasil penjabaran yang di deskripsikan tersebut serta di analisis dengan persentase maka selanjutnya menguraikan maksud dari angkaangka yang terdapat dalam tabel dan lampiran-lampiran maka dari keseluruhan aspek pertanyaan dalam angket tersebut dapat disimpulkan: 
1. Persiapan guru sebelum pembelajaran dalam Pemanfaatan Hasil Modifikasi Pembelajaran Pendidikan Jasmani di SLB-YPAC Cabang Medan berada pada nilai persentase sebesar $90 \%$ dengan katagori sangat tinggi di karenakan guru pendidikan jasmani terlebih dahulu mempersiapkan RPP, guru memeriksa lapangan sebelum siswa memasuki lapangan dan guru melakukan kegiatan pendahuluan, kegiatan inti, dan penutup.

2. Kegiatan pendahuluan pembelajaran dalam Pemanfaatan Hasil Modifikasi Pembelajaran Pendidikan Jasmani di SLB-YPAC Cabang Medan berada pada nilai persentase sebesar $60 \%$ dengan katagori sedang, dikarenakan guru pendidikan jasmani melakukan berdo`a, pemanasan, peregangan, dan langsung ke materi.

3. Kegiatan inti pembelajaran dalam Pemanfaatan Hasil Modifikasi Pembelajaran Pendidikan Jasmani di SLB-YPAC Cabang Medan berada pada nilai persentase sebesar $85 \%$ dengan katagori tinggi.

4. Kegiatan penutup pembelajaran dalam Pemanfaatan Hasil Modifikasi Pembelajaran Pendidikan Jasmani di SLB-YPAC Cabang Medan berada pada nilai persentase sebesar $60 \%$ dengan katagori sedang.

5. Konsep modifikasi pembelajaran dalam Pemanfaatan Hasil Modifikasi Pembelajaran Pendidikan Jasmani di SLB-YPAC Cabang Medan berada pada nilai persentase sebesar $90 \%$ dengan katagori sangat tinggi.

6. Tujuan Modifikasi pembelajaran dalam Pemanfaatan Hasil Modifikasi Pembelajaran Pendidikan Jasmani di SLB-YPAC Cabang Medan berada pada nilai persentase sebesar $90 \%$ dengan katagori sangat tinggi

7. Struktur modifikasi pembelajaran pembelajaran dalam Pemanfaatan Hasil Modifikasi Pembelajaran Pendidikan Jasmani di SLB-YPAC Cabang Medan berada pada nilai persentase sebesar $80 \%$ dengan katagori tinggi

8. Langkah-langkah/ prosedur modifikasi pembelajaran dalam Pemanfaatan Hasil Modifikasi Pembelajaran Pendidikan Jasmani di SLB-YPAC Cabang Medan berada pada nilai persentase sebesar $60 \%$ dengan katagori sedang.

Pemanfaatan Hasil Modifikasi Pembelajaran Pendidikan Jasmani di SLBYPAC Cabang Medan, terbagi atas 2 indikator dan 6 sub indikator yaitu persiapan guru sebelum memulai pembelajaran, kegiatan pendahuluan, kegiatan inti, kegiatan penutup, konsep modifikasi pembelajaran, tujuan modifikasi, struktur modifikasi pembelajaran dan langkah-langkah/ prosedur modifikasi pembelajaran. Untuk menghitung maksud dari angka-angka persentase per indikator terdapat pada tabel dan lampiran-lampiran

Hasil penelitian yang saya amati, sebelum pembelajaran pendidikan jasmani dilakukan terlebih dahulu, guru pendidikan jasmnai menyiapkan RPP yang sesuai dengan tingkat kecacatan yang diderita anak, dan sebelum memasuki materi praktek, guru pendidikan jasmani terlebih dahulu memeriksa kondisi lapangan apakah sudah baik atau tidak, dan setelah itu bapak guru membariskan siswa dan memimpin do`a, setelah itu guru menyuruh siswa untuk pemanasan. 
Setelah bapak guru melakukan pemanasan, lalu bapak guru menyampaikan materi yang sebenarnya dan setelah itu guru menyampaikan materi yang telah dimodifikasi, dan siswapun melaukan materi pelajaran praktek tersebut, sekaligus bapak guru membenahi gerakan yang salah. Dan ada beberapa hasil modifikasi yang telah dilakukan oleh guru pendidikan jasmani, seperti olahraga permainan mengisi air di dalam pipa yang sudah di lubangi dengan gayung, olahraga lompat tinggi yang sudah di modifikasi, alatnya seperti: matras, tali karet, trampoline, olahraga atletik melakukan lari estafet, alatnya seperti: ukuran lapangan yang seadanya, pipa, dan bola voli yang netnya di rendahkan dari ukuran yang normal.

Berdasarkan hasil penjabaran data yang di deskripsikan tersebut serta di analisis dengan persentase maka selanjutnya menguraikan maksud dari angkaangka yang terdapat dalam tabel dan lampiran-lampiran maka dari keseluruhan aspek pertanyaan dalam angket tersebut. Hasil angket tersebut ditunjukkan pada faktor-faktor yang mempengaruhi Pemanfaatan Hasil Modifikasi Pembelajaran Pendidikan Jasmani di SLB-YPAC Cabang Medan yang meliputi persiapan guru sebelum memulai pembelajaran, kegiatan pendahuluan, kegiatan inti, kegiatan penutup, konsep modifikasi pembelajaran, tujuan modifikasi, struktur modifikasi pembelajaran pembelajaran dan langkah-langkah/ prosedur modifikasi pembelajaran.

Berikut ini penjelasan mengenai komponen yang dapat mempengaruhi Pemanfaatan Hasil Modifikasi Pembelajaran Pendidikan Jasmani di SLB-YPAC Cabang Medan:

1. Persiapan guru sebelum pembelajaran. Berdasarkan hasil penelitian dapat disimpulkan bahwa pelaksanaan persiapan guru sebelum pembelajaran sudah hampir maksimal dengan katagori sangat tinggi. Hal ini karena guru selalu mempersiapkan materi ajar yang akan diajarkan kepada siswa, dan membuat Rencana Pelaksanaan Pembelajaran (RPP) sesuai kurikulum dan kemampuan anak.

2. Kegiatan pendahuluan. Pelaksanaan kegiatan pendahuluan dengan katagori sedang, karena rata-rata guru pendidikan jasmani memperhatikan siswa dalam pelaksanaan pembelajaran sedangkan siswa masih kurang melaksanakan apa yang di perintahkan guru, seperti berbaris absen, pemanasan dan berdoa.

3. Kegiatan inti. Kegiatan inti inti berada pada katagori sangat tinggi, karena materi dan modifikasi pembelajaran yang diberikan secara praktis oleh guru yang mengajar karena daya tangkap maupun kemampuan berfikir, kekuatan alat dan gerak anak yang terbatas. Latihan praktis yang dimulai dengan mengfungsikan modifikasi pembelajaran dengan gerak yang ringan kemudian dilanjutkan dengan gerakan yang kompleks. Latihan dapat dilakukan dengan senam mengaktifkan dan menguatkan berbagai kelompok otot, latihan kondisi, latihan untuk rekreasi dan prestasi. kegiatan inti diperaktikkan oleh guru dan siswa belajar mengikuti apa yang dilakukan guru. 
4. Kegiatan penutup. Pelaksanaan proses pendidikan jasmani pada katagori sedang, karena rata-rata guru pendidikan jasmani memberikan kegiatan penutup dengan pendinginan.

5. Konsep modifikasi. Berdasarkan hasil penelitian konsep modifikas dengan katagori sangat tinggi, karena guru pendidikan jasmani telah membuat konsep modifikasi alat seperti olahraga permainan yakni, mengisi air di dalam pipa yang telah dilubang dan anak mengisinya dengan gayung, konsep alat sebelumnya yakni, mengisi pipa yang telah di lubangi dengan pipa yang berukuran lebih kecil.

6. Tujuan modifikasi. Berdasarkan hasil penelitian dapat disimpulkan bahwa pelaksanaan tujuan pembelajaran sudah hampir maksimal dengan kategori sangat tinggi. Tujuan dalam memodifikasi pembelajaran siswa SLBYPAC Cabang Medan telah disesuaikan dengan kondisi anak didik dengan tetap mengacu pada kurikulum yang ada. Tujuan nya untuk meningkatkan aktifitas pembelajaran dan aktifitas gerak anak.

7. Struktur Modifikasi pembelajaran. Berdasarkan hasil penelitian struktur modifikasi pembelajaran mempunyai katagori tinggi. Karena materi yang diajarkan guru mempunyai susunan struktur yang berurutan, dari gerakan yang paling ringan sampai gerakan yang kompleks dengan modifikasi pembelajaran yang di berikan.

8. Langkah-langkah/ prosedur modifikasi. Berdasarkan penelitian prosedur modifikasi mempunyai kategori sangat tinggi. modifikasi pembelajaran. penjas merupakan satu usaha yang strategis untuk menjalankan proses pendidikan dengan baik, mempunyai langkah-lagkah yang sesuai dimulai dari pemanasan, inti dan pendinginan.

\section{Simpulan}

Berdasarkan hasil penelitian pemanfaatan hasil modifikasi pembelajaran pendidikan Jasmani di SLB-YPAC Cabang Medan, dapat disimpulkan bahwa pelaksanakan pembelajaran pendidikan jasmani mendapatkan nilai $77.77 \%$. Termasuk dalam katagori tinggi.

\section{Rujukan}

Arikunto, suharsimi, 1997. Prosedur Penelitian Suatu Pendekatan Praktek. Edisi revisi V. Jakarta: Rineka Cipta

Bahagia, suherman, MA, 2000. Prinsip-prinsip pengembangan dan Modifikasi cabang olahraga. Jakarta: Departemen pendidikan dan kebudayaan direktorat jenderal pendidikan dasar dan menengah bagian proyek penataran guru SLTP Setara D-III

Departemen Pendidikan Nasional, 2006. Standar Kompetensi Dan Kompetensi Dasar Sekolah Menengah Atas Luar Biasa Tunagrahita Ringan (SMALBC), Jakarta: Badan Standar Nasional Pendidikan (BSNP).

Epi Vany, 2010. Survey Pelaksanaan Pembelajaran Pendidikan Jasmani Sekolah Luar Biasa Tunagrahita (SLB-C) Di Kotamadya Medan Tahun Ajaran 2009/2010. Unimed: FIK 
Hasril wijaya, 2009. Survey pelaksanaan pembelajaran pendidikan jasmani SMP Negeri Se-Kecamatan Merbau Kab. Labuhan Batu Tahun ajaran 2008/2009. Unimed: FIK

Muhajir, 2004."Pendidikan Jasmani, Teori, Dan Praktek". Jakarta: Erlangga

Samsudin, 2008. Pembelajaran Pendidikan Jasmani, Olahraga, dan Kesehatan untuk SMA. Jakarta: Litera Prenada Media Group.

Sofian effendi and tukiran, 2012. Metode Penelitian Survey, Edisi reverensi. Jakarta: LP3ES

Sudjana, M.A., M. Sc, 1989. Metode Statistika. Bandung: Tarsito 